\title{
Modelling to Analyse the Process and Sustainability Performance of Forestry-based Bioenergy Systems
}

\section{Elias Martinez-Hernandez}

Mexican Petroleum Institute: Instituto Mexicano del Petroleo

Jhuma Sadhukhan ( $\boldsymbol{\nabla}$ j.sadhukhan@surrey.ac.uk)

University of Surrey

Jorge Aburto

Mexican Petroleum Institute: Instituto Mexicano del Petroleo

Myriam Allieri

Mexican Petroleum Institute: Instituto Mexicano del Petroleo

\section{Steven Morse}

University of Surrey

Richard Murphy

University of Surrey

\section{Research Article}

Keywords: waste-to-energy, life cycle assessment (LCA), techno-economic analysis, social life cycle assessment (SLCA), community social deprivation analysis, water-energy nexus

Posted Date: July 20th, 2021

DOl: https://doi.org/10.21203/rs.3.rs-714017/v1

License: (c) (i) This work is licensed under a Creative Commons Attribution 4.0 International License.

Read Full License

Version of Record: A version of this preprint was published at Clean Technologies and Environmental Policy on February 16th, 2022. See the published version at https://doi.org/10.1007/s10098-022-022781. 


\title{
Modelling to analyse the process and sustainability performance of forestry-based
}

\section{bioenergy systems}

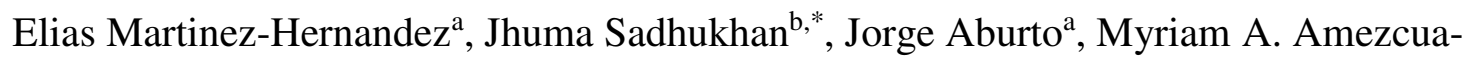

$$
\text { Allieri }^{\mathrm{a}} \text {, Steven } \text { Morse }^{\mathrm{b}} \text {, Richard Murphy }{ }^{\mathrm{b}}
$$

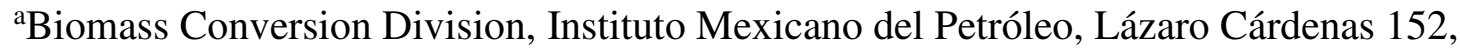

$$
\text { Mexico City, 07730, Mexico }
$$

${ }^{\mathrm{b}}$ Centre for Environment and Sustainability, University of Surrey, Guildford GU2 7XH, UK *Corresponding author: jhumasadhukhan@gmail.com

\begin{abstract}
This study develops a novel mathematical modelling framework for biomass combined heat and power systems (CHP) linking physicochemical/thermodynamic characteristics and life cycle sustainability. A total of twenty-nine indicators for the process (4), economic (5), environmental (8) and social global (5) and local (7) aspects have been analysed for sustainability. These are biomass throughput, electricity and steam generations and CHP efficiency; internal rate of return, capital, operating and feedstock costs and cost of production; global warming, fossil, land and water use, acidification, urban smog, eutrophication and ecotoxicity potentials; labour rights \& decent work, health \& safety, human rights, governance and community infrastructure; total forest land, direct/indirect jobs, gender equality and energy-water-sanitation access for communities, from biomass characteristics (carbon and hydrogen contents), energy demands and economic parameters. The model is disseminated as an open-web-resource https://tesarrec.web.app/sustainability/chp. In a case study approach, from $12.47 \mathrm{kt} /$ year forestry residue, $1 \mathrm{MWe}$ is generated with an associated low-pressure steam generation of $50 \mathrm{kt} /$ year, at a cost of production of $\$ 0.023 / \mathrm{kWh}$, making "affordable and clean energy" (the UN Sustainable Development Goals, SDG7) for marginalised/poor communities. Bioenergy can curb $>90 \%$ greenhouse gas emissions and primary energy, $6 \mathrm{kt} \mathrm{CO}_{2}$ eq and 74
\end{abstract}


TJ annually, 87-53\% water consumption, acidification and eutrophication, and $29-18 \%$ urban smog and ecotoxicity, compared to fossil-based counterpart. All five social themes in the Central American cluster countries can be improved by bioenergy. In addition to SDG7, SDG6: "clean water and sanitation for all" can be delivered by forestry-based bioenergy system.

Keywords: waste-to-energy, life cycle assessment (LCA), techno-economic analysis, social life cycle assessment (SLCA), community social deprivation analysis, water-energy nexus.

\section{Introduction}

Energy poverty and environmental impacts are global problems affecting developing countries disproportionately. The energy-environmental nexus issues are complex, affecting the ecosystem, human health and economic performance of countries and corporations (Halog and Manik 2011). Bioenergy can provide a sustainable solution to these nexus challenges (Martinez-Hernandez and Samsatli 2017). The need for a quantitative modelling framework to analyse the sustainability of bioenergy systems to tackle nexus challenges is indisputable and has been tackled by two main approaches, optimisation-based (Ong et al. 2021) and simulationbased (Sadhukhan et al. 2021). The former approach involves the minimisation of objective functions such as economic, environmental and social costs, etc. under the various supply and demand constraints. By applying mathematical programming, independent design and operating variables are optimised for the best tradeoffs and outcomes within the constraints (Sadhukhan et al. 2014). A simulation-based approach allows integrated process conceptualisation based on interactive mass, energy and momentum transfer models of underlying phenomena at unit or flowsheet scale. Both the approaches analyse scenarios and test the sensitivity of independent variables on output results, which can be techno-economic, environmental or social performance (Sadhukhan et al., 2014).

Bioenergy is primarily provided by a combined heat and power system (CHP) utilising biobased residues (Wan et al. 2016a). Forestry-based wood residues are receiving greater attention 
in the literature (Fitzpatrick 2016). A CHP is flexible in nature in terms of the provision of energy vectors, which, however, usually take the form of electricity and heat, the ratio between energy vectors and energy efficiency depending on the demands of the surrounding system. CHP comprises a biomass boiler to turn boiler feed water into high pressure superheated steam generation that is expanded in steam turbines to generate electricity. Steam can be extracted at any pressure depending on the system demand. The CHP system can be best analysed by an Aspen Plus simulation model (Wan et al. 2016b) applied in Mexico's bioenergy context (Martinez-Hernandez et al. 2017). However, for accessibility, a generic model must be developed and transferred into a usable platform, in this case, which is an open web resource (Sen 2020). The modelling platform developed this way allows testing of input variables, such as energy currency of biomass fuel to CHP, on the sensitivity of output results. Output results encompass underlying technical, economic, environmental and social impacts that are deemed important for sustainability analysis of CHP. This study thus focuses on a type IV system, "sustainable technology", and group 3 sustainability analysis, "sustainability indicators", following the systematic categorisations of systems and sustainability metrics (Sikdar 2003). Here, we present a targeted literature review concerning the modelling of the CHP and sustainability analysis using data from the literature and forest-based cooperative.

Sahu and Prabu (2021) have simulated a CHP using Aspen Plus (Sahu and Prabu 2021). Their Aspen Plus simulation model comprises a combustor model using RGibbs and high, medium and low pressure steam turbine models. The thermodynamic property package is PengRobinson. The TRNSYS tool (Klein et al. 2017) has been applied to simulate biomass boiler and steam turbines (Żołądek et al. 2021). Aspen Plus simulation and optimisation models for biomass-based heat and power generations are noted through turbine cycles (Rezaei et al. 2021). In the context of bioethanol production process simulation using Aspen Plus, a utility boiler has been shown (Petersen et al. 2021). The use of computational fluid dynamics 
packages using detailed geometry and meshes is also noted in the literature (Puig-Gamero et al. 2021), which may not be relevant to the present study due to the aim of flowsheet or whole system simulation. There is a handful of research literature on carbon capture and storage (CCS) associated with CHP. Notably, the investment cost of CCS can be up to $\$ 1150 / \mathrm{kW}$, which is $20 \%$ of the total capital investment of an integrated gasification combined cycle system (IGCC) comprising gasifier, sour gas removal, water gas shift reactors, CCS, gas turbine, steam turbine, heat recovery steam generator or boiler and steam network system and air separation unit ( $\mathrm{Ng}$ et al. 2010). Heat integration is key to the reduction of the cost of electricity generation, which can be $\$ 0.066 / \mathrm{kWh}$ from an integrated IGCC with CCS (Ng et al. 2010). Complete recovery of useful heat is possible by turning boiler feed water into high pressure steam generation through sequential heat recovery from the heat recovery steam generator of the exhaust gas from the gas turbine, low and high temperature water gas shift reactors and cooler of the gas from the gasifier ( $\mathrm{Ng}$ et al. 2010). However, the system is too complex to operate on a community scale. This makes the design of bioenergy systems challenging, which needs to be simple for operation by the communities as well as efficient to guarantee a minimum price for energy affordability to poor marginalised communities that may even be lacking foundational energy-water-sanitation services (Sadhukhan et al. 2019a). Carbon dioxide capture and reuse in the production of high value products are other strands of research literature on carbon dioxide capture that have also been published ( $\mathrm{Ng}$ et al. 2013). The other focus of recent CHP studies entails biomass integrated gasification combined cycle and biomass integrated gasification fuel cell systems, rigorous simulation and efficiency analyses of which have been published earlier (Sadhukhan et al. 2010). As can be seen, even though we have considered highly integrated advanced efficient bioenergy systems, these are not compatible systems for serving poor marginalised communities. Moreover, the literature notes that much of the study focus is on European regions (Wang et al. 2018). This leaves an 
important gap in the literature that is to apprehend a system for "affordable and clean energy" and "clean water and sanitation" (the United Nations Sustainable Development Goals, SDG67) (UN SDG 2015) for poor marginalised communities in developing countries.

Sustainability assessment of bioenergy has been the main emphasis of the scientific research communities. Sustainability assessment needs consideration of underlying criteria, technical, economic, environmental and social (Sikder 2003). While participatory approaches are more common (Emmanuel-Yusuf et al. 2017), analytical approaches modelling intrinsic interactions are emerging for life cycle sustainability assessment of systems (LCSA) (Sadhukhan et al. 2021). There are also debates on the selection of the sustainability criteria and whether to present them as individual criteria or as a single score by assigning weights from stakeholders to the multi-criteria. The literature is very rich in multi-criteria decision analysis, for example, Wang et al. (2018). González-Cruz et al. (2021) have provided a comprehensive overview of the multi-criteria methods (González-Cruz et al. 2021). The methods are useful for decision making from a set of choices (Niekamp et al. 2015). Another strand of research encourages the presentation of all plausible underlying sustainability criteria to stakeholders so that they are best informed of possible consequences and tradeoffs. The sustainability analysis framework adopts life cycle thinking. LCSA analyses comprise (environmental) life cycle assessment (LCA), life cycle costing (LCC) and social life cycle assessment (SLCA) following the ISO14040-44 and ISO26000 standards. LCA of bioenergy considers global warming potential, fossil energy use and land use as the main criteria. Forty-four literature works have been identified concerning these important environmental consequences of bioenergy (Roos and Ahlgren 2018). Primary analysis on sustainable biomass and bioenergy availability using a geographic information system, reveals an annual useful energy generation potential of 670.3 and 30.72 PJ from available agricultural and forestry land in Mexico (Honorato-Salazar and Sadhukhan 2020). Highly integrated bioenergy systems comprising green diesel synthesis by 
hydroprocessing and biodiesel synthesis by transesterification have been designed to offset these environmental impacts in Mexico (Martinez-Hernandez et al. 2014). Other deemed important atmospheric and aquatic impacts include acidification, urban smog, eutrophication and ecotoxicity potentials, etc. (Sadhukhan et al. 2014). The economic indicators are profit, operational performance and capital, processing, utility and waste costs (de Faria et al. 2021). The cost parts can be aligned with the process engineering cost calculations for technoeconomic analysis, direct, indirect and working capital, and fixed (including labour), variable (including processing, utility and waste costs) and miscellaneous operating costs, which have long-standing standard methods of calculation (Sadhukhan and Martinez-Hernandez 2017). Furthermore, the cost of production applying the net present value analysis and all the cost components is a useful indicator that captures all intrinsic process and macro-scale systemic variables (Sadhukhan et al. 2004). Compared to LCA and LCC, SLCA is an emerging but important area of research that must be distinctly applied rather than amalgamated to LCA to sustainability analysis study (Clift 2014). The SLCA following the ISO26000 standard suggests five social themes and twenty-two sub-themes for the representation of the social performance of a system (Shemfe et al. 2018). These social themes are aligned with the framework applied for recent literature classification (de Faria et al. 2021). The social hotspot database (SHDB) by New Earth is the most popular global database assigning scores to the various social themes in individual product sectors in individual countries (Norris et al. 2014). LCA, LCC and SLCA methods have a sound mathematical grounding for quantitative analyses of systems (Sadhukhan et al. 2021). Countless publications exist in LCA, LCC, SLCA and LCSA approaches (Visentin et al. 2020). However, studies only scarcely attempt to link fundamental process modelling through to sustainability assessment, with some exceptions (e.g. Sadhukhan et al. 2019b). This study thus aims to link a fundamental novel process model and sustainability analysis of bioenergy as far as possible using analytical tools and available 
data from the forest-based cooperative and literature. In addition, local community level indicators are analysed for the UN SDG (UN SDG 2015) benefits of bioenergy.

The paper is structured as follows. The materials and methods section discusses the mathematical models and modelling bases for technical, economic, LCA, SLCA and local community-level socio-economic performance analyses. A case study approach is then taken to demonstrate the benefits of a forest-based cooperative in the poorest most deprived parts of Mexico. This case study provides a useful context for waste-to-energy approaches and for exploring how the modernisation of energy supply in forest-based supply chains through CHP can support the UN SDGs as well as policy programmes.

\section{Methodology}

The methodological components and structure followed in this study are depicted in Figure 1. The first step is to characterise the case study in terms of location, communities and type of organisations involved, poverty or social deprivation indicators available, biomass resource and bioenergy technology, bioenergy products and end uses. Scenarios are built and modelled to evaluate their techno-economic and environmental outcomes from fundamental physicochemical characterisations of CHP, biomass resources and supply logistics. SLCA indicators are sourced from the proprietary SHDB (Norris et al. 2014). Some important socioeconomic indicators apply to local conditions obtained from the organisation managing the forest. Other indicators apply at the country level making them more relevant for comparisons between the countries in The Central American Electrical Interconnection System (SIEPAC) (Ecchevarria et al. 2017).

The following scenarios are evaluated.

1. Present scenario with limited generation (LG). This corresponds to an existing bioenergy generation capacity. In this case, the bioenergy generated is only used to replace grid electricity and fossil fuel within the sawmill. The surrounding communities have access to 
electricity from the grid but there is a small percentage of households without electricity access.

2. Generation Expansion (GE) scenario. This corresponds to leveraging the use of biomass readily available and the existing generation capacity at the sawmill facility. The surplus electricity is provided to the surrounding communities to improve electricity access.

A bottom-up approach, modelling the bioenergy processing and conversion is adopted, which allows the inclusion of different technology parameters and thus an exploration of resulting technical, economic and environmental impacts. Next, the scenarios are evaluated using the indicators that are deemed important in selecting bioenergy systems for sustainability while embedding a life cycle thinking philosophy. This allows for the identification of social hotspots with potential social issues or trade-offs between benefits and negative impacts. It is worth noting that other contextual factors such as regulations and policy constraints are embedded in the construction of scenarios; for example, the self-generation is capped to a certain capacity, and there are also constraints to exported electricity to the grid.

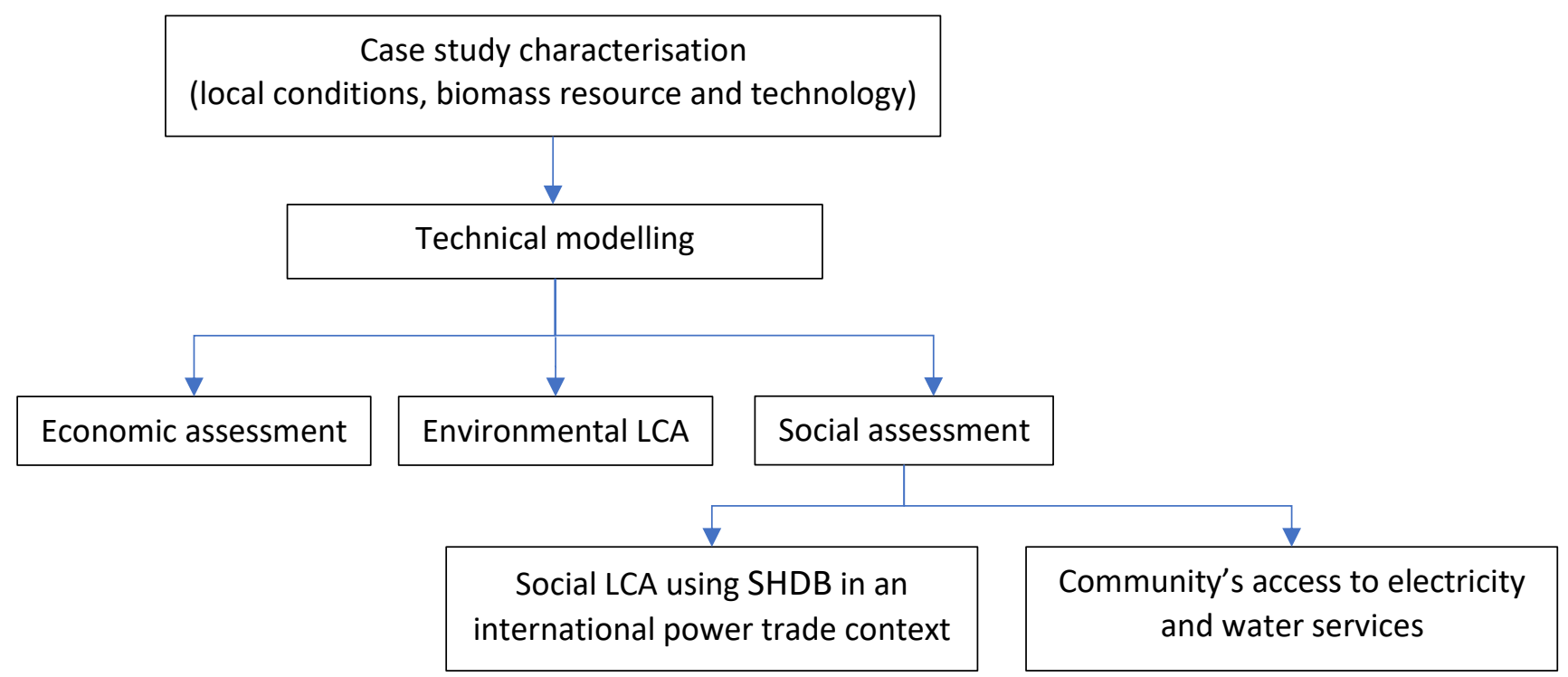

Figure 1. The structure used for sustainability evaluation of bioenergy.

Bioenergy process modelling 
The simulation of bioenergy systems has been carried out using the TESARRECTM CHP module (Sen 2020) and validated using the IMP's (Instituto Mexicano del Petróleo) in-house software tool IMPBio2Energy® built upon the plant data (Martinez-Hernandez et al. 2021). This robust technical performance model of the system illustrated in Figure 2 comprises Equations 1-4 to estimate biomass throughput, steam generation by the system, and electricity and CHP generation efficiencies from the electricity rating of the CHP.

Biomass throughput (wet) $\frac{\mathrm{kg}}{\text { hour }}=\frac{\left(1560 \times \text { Electricity generation } \frac{G W h}{\text { year }}-0.23\right)}{(C \times 0.375+H \times 1.154)} \times \frac{1}{\epsilon_{\text {Boiler }}} \times$ $\begin{array}{ll}\frac{1}{\epsilon_{S T 1}} \times \frac{1}{\epsilon_{S T 2}} \times \frac{100}{(C+H)} \times \frac{100}{(100-M)} & \text { Equation } 1\end{array}$

Carbon and hydrogen contents (dry basis) in wt $\%, C$ and $H$, constitute the fundamental basis of the equations. $C$ and $H$ signify the energy currency of biomass. They have a calorific value of 37.5 and $115.4 \mathrm{MJ} / \mathrm{kg}$, respectively. The term $(C \times 0.375+H \times 1.154)$ signifies energy content within carbon and hydrogen in biomass, which is higher than the energy content (or calorific value) of the biomass due to the presence of inert in the biomass. This electricity generation from the back pressure steam turbine (dependent variable) has been plotted against the term $(C \times 0.375+H \times 1.154)$ (independent variable) using the results of simulation in Aspen Plus 8.8 to obtain the first term on the right side in Equation 1. Adjustments are needed due to the efficiencies, such as, of boiler and (isentropic and mechanical) of back pressure steam turbine, $\in_{\text {Boiler }}, \epsilon_{S T 1}$, and $\epsilon_{S T 2}$, respectively, and to consider the presence of moisture in the biomass, $M$.

Equation 2 estimates the production rate of low pressure superheated steam at and above 1 atmospheric pressure.

Steam generation $\frac{\mathrm{kg}}{\text { hour }}=$ 
$\frac{\left(1560 \times \text { Electricity generation } \frac{G W h}{\text { year }}-0.23\right)}{(C \times 0.375+H \times 1.154)} \times \frac{1}{\epsilon_{\text {Boiler }}} \times \frac{1}{\epsilon_{S T 1}} \times \frac{1}{\epsilon_{S T 2}} \times(0.2807 \times(C \times 0.375+$

$$
H \times 1.154)+0.0463)) \quad \text { Equation } 2
$$

The effect of energy content within carbon and hydrogen in biomass is captured in the final term on the right-hand side of Equation 2. The final term on the right-hand side in Equation 2 is based on the amount of steam generation concerning energy content within carbon and hydrogen in biomass using the results of simulation derived from Aspen Plus 8.8.

Equations 3-4 calculate the electricity, and heat and electricity generation efficiencies based on target output electricity generation, low pressure superheated steam generation and low heating value $(L H V)$ of biomass.

Electricity generation efficiency

$$
=\frac{411 \times \text { Electricity generation } \frac{G W h}{\text { year }}}{\text { Biomass throughput (wet) } \frac{\mathrm{kg}}{\text { hour }} \times \text { Biomass (wet) LHV } \frac{\mathrm{MJ}}{\mathrm{kg}}}
$$

Equation 3

CHP generation efficiency

$$
=\frac{\left(411 \times \text { Electricity generation } \frac{G W h}{\text { year }}+2.77 \times \text { Steam generation } \frac{\mathrm{kg}}{\mathrm{hour}}\right)}{\text { Biomass throughput }(\text { wet }) \frac{\mathrm{kg}}{\mathrm{hour}} \times \text { Biomass }(\text { wet }) \text { LHV } \frac{\mathrm{MJ}}{\mathrm{kg}}}
$$

Equation 4

411 is the factor employed to convert Electricity generation $\frac{G W h}{\text { year }}$ into MJ/hour: $\frac{1000000 \times 3.6}{24 \times 365}$. This conversion factor is needed as usually, the annual electricity demand is available in GWh. The low pressure superheated steam at and above 1 atmospheric pressure and at $105^{\circ} \mathrm{C}$ has an enthalpy of $2.77 \mathrm{MJ} / \mathrm{kg}$. 


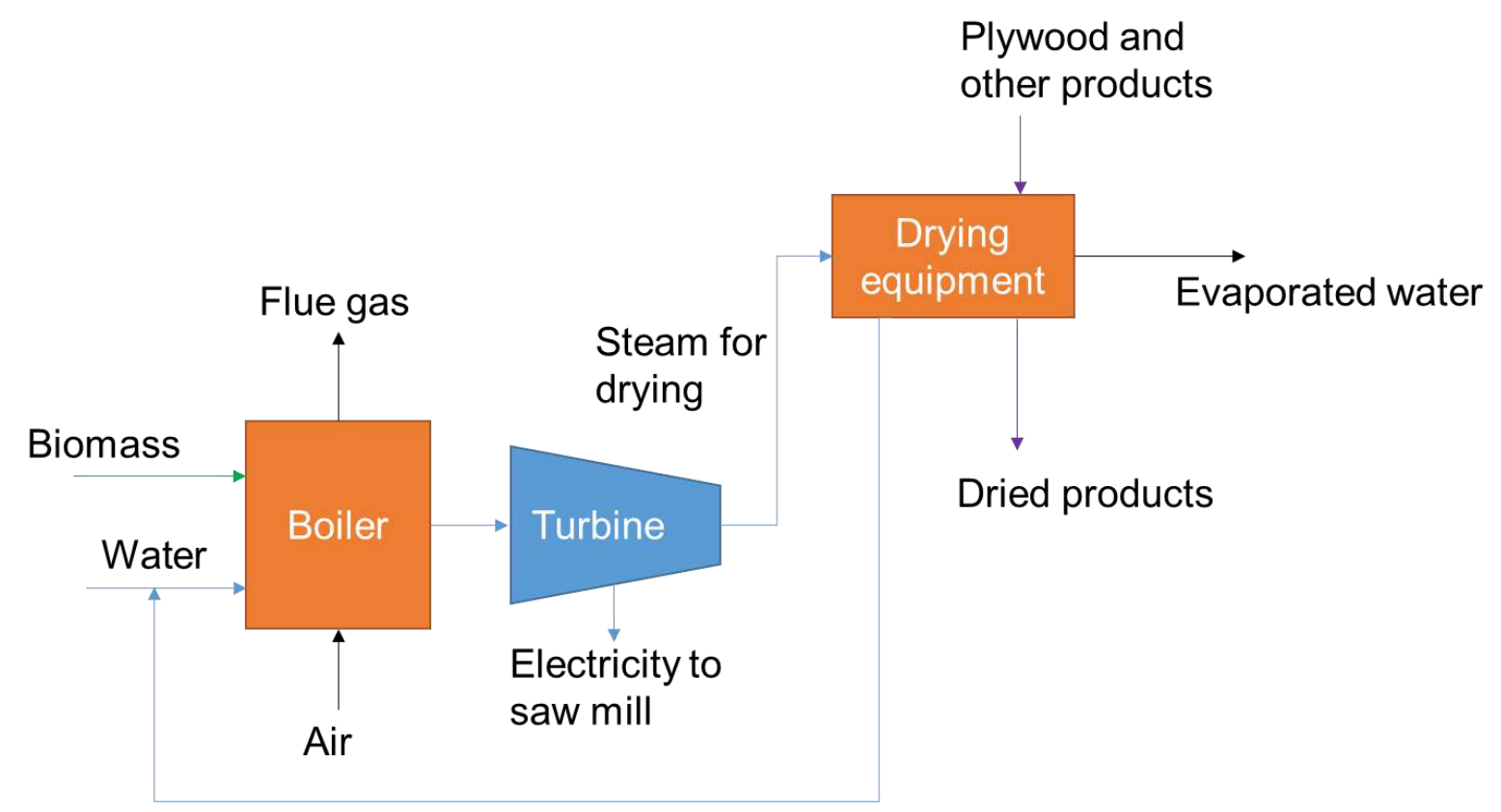

Figure 2. CHP configuration.

\section{Bioenergy economic analysis}

Capital cost, operating cost, cost of production of CHP and the discounted cash flow analysis over the life cycle of the CHP are determined using Equations 5-12 and parameters (Sadhukhan et al. 2014). The capital cost is determined from Equation 5 by first estimating the delivered cost of each component in the CHP, i.e. boiler and steam turbine and steam system. An Installation factor is then applied to estimate the total capital cost.

Capital cost $=\left(\sum_{i} D C_{i} \times\left(\frac{\text { present amount }_{i}}{\text { base production rate }}\right)^{\text {scale factor }_{i}}\right) \times$ Installation factor

Equation 5

$D C_{i}$ is the delivered cost of each component $i$ in the CHP, $i \in$ boiler, steam turbine and steam system, for their reference or base production rate . Their base production rate and $_{i} C_{i}$ are as follows.

For the boiler, the base size is $0.62 \mathrm{~kg} / \mathrm{s}$ of biomass and $D C_{i}$ for its base size is $\$ 0.4323$ million (Wan et al. 2016a-b). For the steam turbine and steam system, the base size is $10.3 \mathrm{MW}$ electricity output and $D C_{i}$ for its base size is $\$ 5.1$ million (Sadhukhan et al. 2014). The term 
scale factor $_{i}=0.7$ captures the effect of the economy of scale such that the costeffectiveness increases with the increasing size of the unit.

The Installation factor or the Lang factor is applied to take account of the capital costs due to i) installation, instrumentation \& control, piping, electrical systems, buildings (including services), yard improvements and service facilities (other components of direct capital cost, in addition to the delivered cost of equipment); ii) engineering \& supervision, construction expenses, legal expenses, contractors' fees and contingency (indirect capital cost); and iii) working capital, to make up for the total Capital cost (Sadhukhan et al. 2014).

Thereafter, the net present value $\left(N P V_{y}\right)$ calculation in a given year $y$ of the CHP operation is applied (Equation 6) to take into account the depreciation of the economic margin with time.

$$
\begin{aligned}
& N P V_{y}=N P V_{y-1}+\frac{(\text { Product value-Opex-Capex })}{(1+I R R)^{y}} \\
& N P V_{y=0}=\text { Capital cost }
\end{aligned}
$$

$I R R$ is the internal rate of return expressed as a fraction. Capex is an Annual Capital Charge (as a fraction) applied to the Capital cost (Equation 7). Opex is the operating cost (sum of the fixed operating cost dependent on indirect annual capital cost and the labour dependent fixed operating cost, applied with a multiplier (Equation 8). The fixed operating cost dependent on indirect annual capital cost is dependent on the Capital cost (Equation 9). The labour dependent fixed operating cost is a function of Biomass throughput (wet) $\frac{\mathrm{kg}}{\text { hour }}$ (Equation 10).

Capex $=$ Annual Capital Charge $\times$ Capital cost Equation 7 Opex $=a \times($ fixed operating cost dependent on indirect annual capital cost + labour dependent fixed operating cost) Equation 8 fixed operating cost dependent on indirect annual capital cost $=$ $\frac{\text { Capital cost }}{\text { Installation factor }} \times$ Annual Capital Charge $\times b \quad$ Equation 9 
labour dependent fixed operating cost $=c \times$ Biomass throughput (wet) $\frac{\mathrm{kg}}{\text { hour }}$

Equation 10

$a, b$ and $c$ are multipliers of the respective cost components to account for a larger set of cost components (Sadhukhan et al. 2014). The value of $a$ in Equation 8 is 1.3 to account for the other costs such as research and development costs, sales expenses and general overheads.

The indirect capital cost is 1.26 times the delivered cost of equipment for solid-fluid processing systems. Furthermore, the fixed operating cost dependent on the indirect capital cost is 0.15 $\begin{array}{llll}\text { times the } & \text { indirect } & \text { capital } & \text { The }\end{array}$ fixed operating cost dependent on indirect annual capital cost includes the following cost items: maintenance, capital charges, insurance, local taxes and royalties. Thus, the value of $b$ in Equation 9 is $1.26 \times 0.15=0.19$.

The labour dependent fixed operating cost is 1.9 times the personnel cost. The fixed operating cost dependent on the personnel cost includes the following cost items: labour, laboratory, supervision and plant overheads. In TESARREC ${ }^{\text {TM }}$, the personnel cost is $\$ 52033$ per $\mathrm{t} / \mathrm{h}$ throughput. Thus, the value of $c$ in Equation 10 is $1.9 \times 52033 / 1000000=0.1$.

Product value in Equation 6 is the multiplication between the price and rate of production of individual products (electricity and low pressure superheated steam) (Equation 11).

Product value $=$ Electricity price $\times$ Electricity generation + Steam price $\times$ Steam generation Equation 11 Appropriate conversion factors are applied to have the cost analysis in a consistent unit. Equation 12 shows the cost of production of CHP.

Cost of CHP production

$$
=\frac{(\text { Capex }+ \text { Opex })+\text { Biomass cost }}{\text { Electricity generation } \frac{G W h}{y e a r} \times \frac{\text { CHP generation efficiency }}{\text { Electricity generation efficiency }}}
$$

Equation 12 


\section{LCA of bioenergy}

Biomass input and energy output are the key linkages between the process model and the LCA model. Biomass input and energy output evaluations obtained from the process model are used to analyse the LCA of bioenergy. By the ISO14040-44 International Standards for LCA, the selection of impact categories for the life cycle impact assessment (LCIA) should be appropriate to the system's environmental performance. Supply chain activities included within the system boundary for environmental impact characterisations are biomass chipping, diesel consumption in machinery, biomass harvesting, biomass forwarding, infrastructure including CHP and exhaust emissions from the CHP. Eight deemed impact categories are selected for the environmental impact characterisations of the present study as shown in Table 1. The LCIA methodologies to characterise inventories into impacts are shown alongside. The LCIA methodologies used for the characterisation factors are the IPCC global warming potential over 100 years, CML for the fossil resource depletion potential, ILCD for the photochemical ozone formation potential, TRACI for the acidification, eutrophication and ecotoxicity potentials, and ReCiPe for water consumption. Following the ISO14040-44, mix and match between LCIA methods is a good indication of a fundamental understanding of environmental drivers for a system. These life cycle impact categories are fundamental to LCA studies, hence, for their detailed characterisation methods, a fundamental text is recommended (Sadhukhan et al. 2014). Furthermore, the land impact for biomass residue availability for CHP is noted through primary data collection from the forest-based cooperative. These impact categories represent a wide coverage of impacts on the atmosphere, water and ecosystem. While the environmental impact categories generally considered to be of the highest interest for energy systems (including bioenergy) are global warming potential and fossil resource consumption (aka. abiotic depletion potential (fossil fuels)), a wider range of impact categories is recommended to present a more complete picture of the system, its potential environmental 
impacts and potential trade-offs between impact categories (Sadhukhan et al. 2014). All nonprimary, data used for modelling the forestry residue CHP and the displaced fuel oil CHP including respective supply chain logistics are sourced from Ecoinvent 3.0 life cycle inventory (LCI) database. The selected Ecoinvent 3.0 LCI databases are \{MX: Mexico\}:

Forestry residue CHP: Electricity, high voltage $\{\mathrm{MX}\} \mid$ heat and power co-generation, wood chips (allocation, cut-off by classification - system)

Fuel oil CHP: Electricity, high voltage $\{\mathrm{MX}\} \mid$ electricity production, oil (allocation, cut-off by classification - system)

Table 1. Environmental impact categories selected for the LCIA.

\begin{tabular}{lcc} 
Impact category & LCIA methodology & Unit \\
\hline Global warming potential (100 yrs) & IPCC & $\mathrm{kg} \mathrm{CO}_{2}$ eq \\
Abiotic depletion potential (fossil fuels) & $\mathrm{CML}$ & $\mathrm{MJ}$ \\
Photochemical ozone formation potential & ILCD & $\mathrm{kg} \mathrm{NMVOC} \mathrm{eq}$ \\
Acidification potential & TRACI & $\mathrm{kg} \mathrm{SO}_{2}$ eq \\
Water consumption & $\mathrm{ReCiPe}$ & $\mathrm{m}^{3}$ \\
Eutrophication potential & TRACI & $\mathrm{kg} \mathrm{N}$ eq \\
Ecotoxicity potential & TRACI & $\mathrm{CTUe}$ \\
Land use or sustainable forestry residue & Primary data from \\
availability per land & $\mathrm{kg} / \mathrm{m}^{2}$ \\
\hline (NMVOC = non-methane volatile organic compound; CTU = cumulative toxicity unit)
\end{tabular}

\section{SLCA of bioenergy}

The SLCA assessment is based on the social impact themes recognised in the SHDB shown in Table 2. Several attempts have been made to develop indicator sets for SLCA, including those of the UNEP (United Nations Environmental Programme) and the SETAC (Society of Environmental Toxicology and Chemistry). They have proposed five social themes and twenty-two sub-themes to assign scores and estimate the overall social score using a weighted summation methodology. The SLCA themes are 1) labour rights and decent work, 2) health and safety, 3) human rights, 4) governance and 5) community infrastructure. These themes and their sub-themes are applicable at a local level. The life cycle thinking philosophy embedded in the SLCA methodology helps to interconnect local and global level social themes and sub- 
themes and focus on targeted indicators for socio-economic sustainability. The common consideration of life cycle stages in the analyses makes SLCA more comprehensive for the sustainability evaluation of bioenergy (Sadhukhan et al. 2014).

Table 2. Social impact themes and sub-themes.

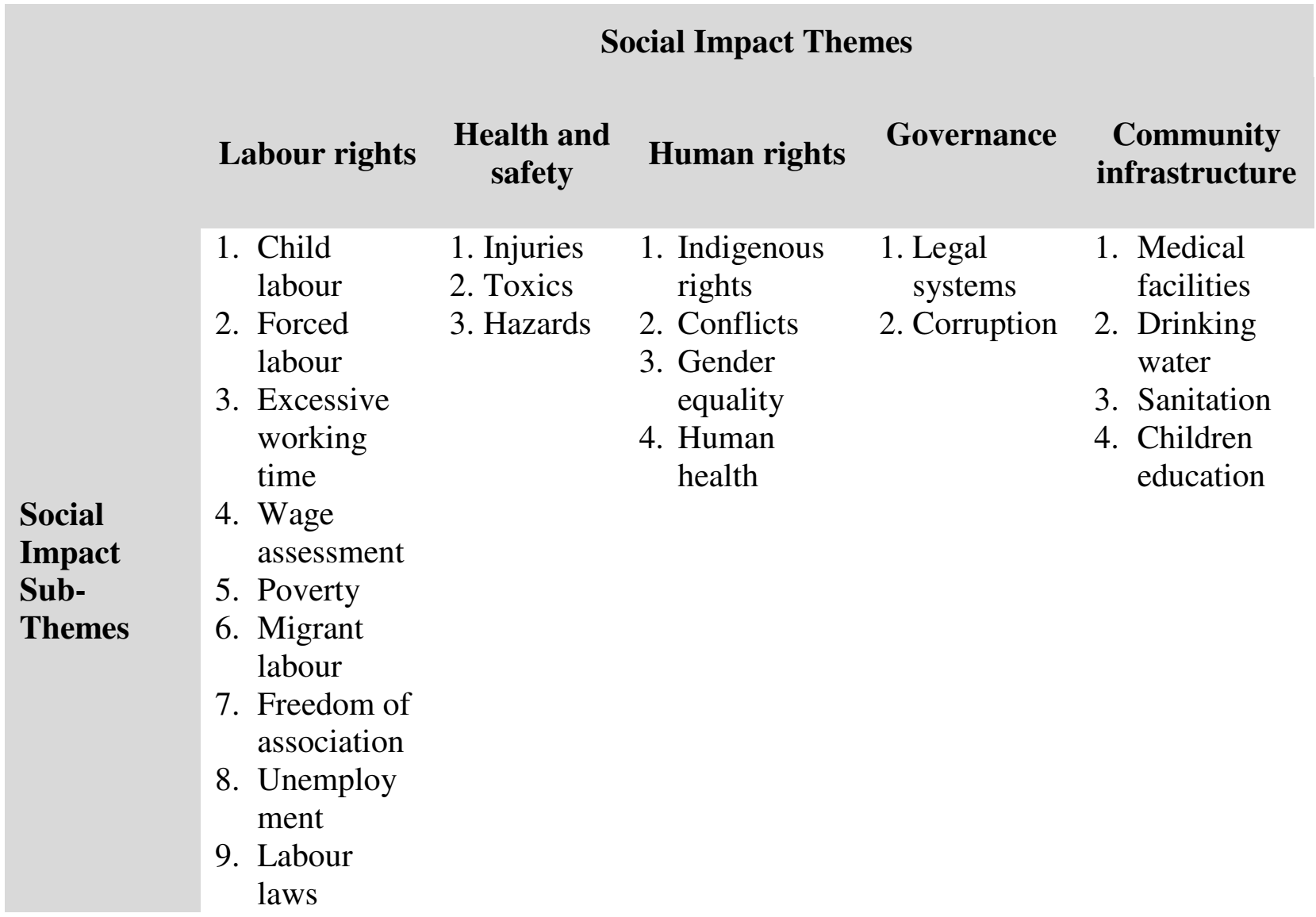

The supply chain interactions are considered in the computation of the total index of a theme for a given sector in a given country. In constructing the SHDB, we have combined the UN Comtrade Database on import-export of electricity between countries (Comtrade 2019) and the social theme scores for the energy sector in the countries using the SHDB (Norris et al. 2014). The unit used to express the social impact themes is the medium-risk hour (mrh) in terms of labour-hours for a given production rate.

In this case, the countries in The Central America Electrical Interconnection System (Ecchevarria et al. 2017) can be compared to show which flow direction of electricity between 
two countries would benefit in terms of social theme score. The individual social theme scores are factored by the netted fractional imports considering the supply chain and these factored individual social theme scores are added to give a total social theme score for a given sector in a given country. Equation 13 shows the individual total social theme score calculation.

Index $_{T, p}=\sum_{c} R_{T, p, c} \times \operatorname{Frac}_{p, c} \quad$ where: $\sum_{c} \operatorname{Frac}_{p, c}=1 \quad$ Equation 13

Index $_{T, p}$ is the individual total social theme score for a given product $\mathrm{p}$ in each country. $R_{T, p, c}$ is the risk of a theme in the country of origin as well the countries (c) exporting to the given country (the countries of origin approach) or in the entire supply chain influencing the exports to the given country (the life cycle approach), the product $p . F r a c_{p, c}$ is the fraction of the product $p$ produced in the country or imported from other countries considering their corresponding supply chains.

\section{Results and discussion}

\section{Data from forest-based community}

The methodology is applied to a case study on forestry-based energy services for poor marginal communities (Luján-Álvarez et al. 2015). Table 3 shows primary data on the characteristics of the forest-based cooperative run and managed by communities and communal forest landowners organised in what is known in Mexico as 'Ejidos'. The primary data in Table 3 that also include biomass availability and land use are obtained from the forest-based cooperative. The communities provide forestry waste to a sawmill in Durango State, considered one of the main stakeholders. The sawmill then uses residues to generate bioenergy for self-sufficiency. The sawmill which generates the biomass is in the community of Santiago Papasquiaro, Durango and belongs to the Sezaric cooperative registered as a Rural Association of Collective Interest. The forest trees are of the genera Pinus spp. The major products are plywood and pinewood boards. The company is certified by the Forest Stewardship Council. The area of influence of the cooperative is depicted in Figure 3 and spans 8 municipalities in Northeast 
Durango State (Santiago Papasquiaro, Otáez, Canelas, Topia, Tepehuanes and some parts of Guanaceví, Tamazula and San Dimas). The map also shows the degrees of social deprivation of these municipalities according to the value of indicators for 2015 reported by the National Council for the Evaluation of Social Development Policy (CONEVAL 2010). Figure 3 shows that at least five of the municipalities have a medium degree of social deprivation while one municipality (Tamazula) classified as of high social deprivation and two as having low social deprivation (Santiago Papasquiaro and Tepehuanes). Social deprivation indicators reported by CONEVAL include poor access to a potable water and sewage network and poor access to electricity, among other indicators. These three indicators are used in the results section to analyse the potential positive impact from the CHP utilising wood residues on enabling access to electricity and water services (SDG6-7).

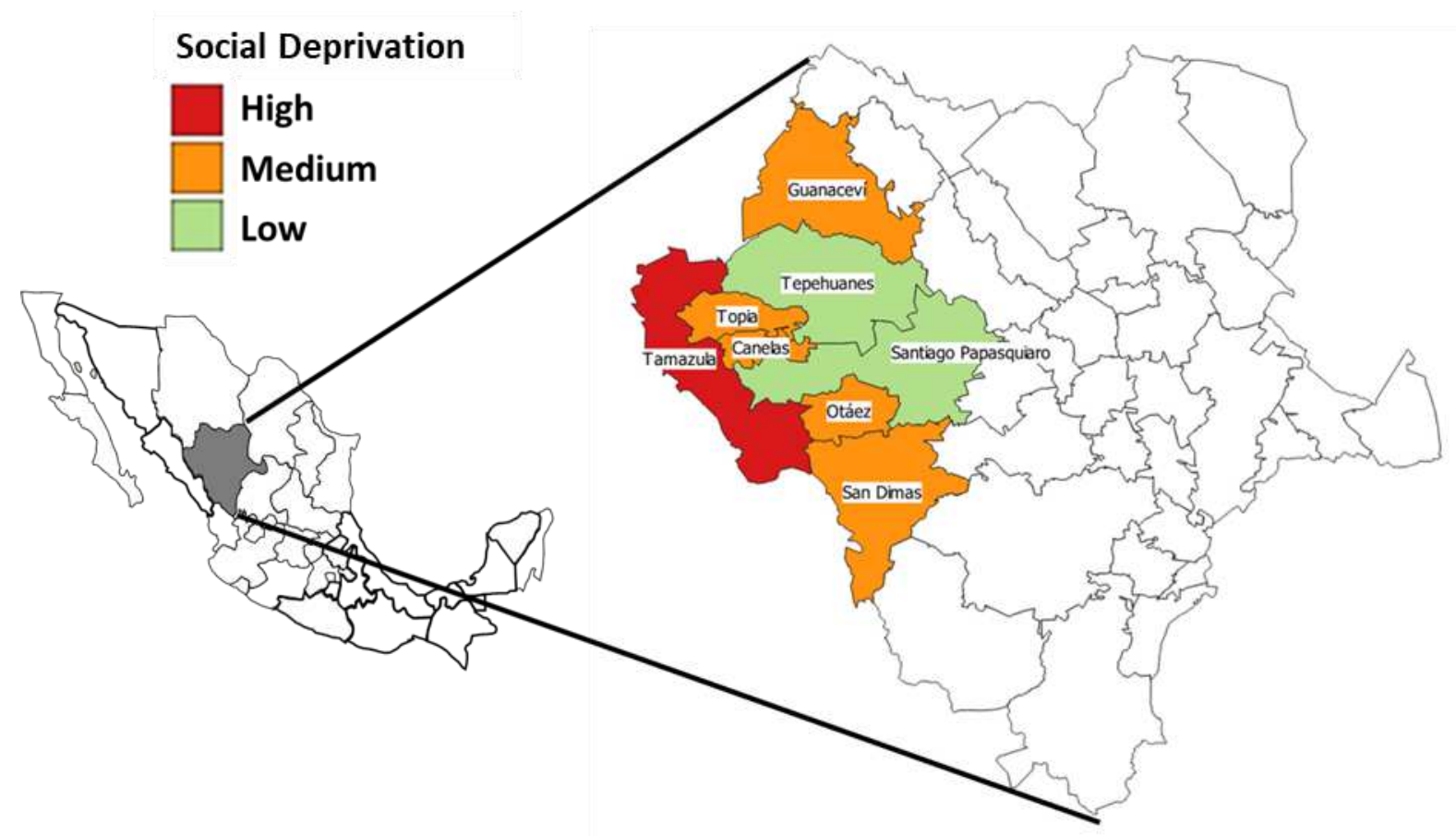

Figure 3. Degree of social deprivation in the areas of influence of the case study for bioenergy generation in a sawmill in Durango state, Mexico.

Table 3. Characteristics of the community-managed forest and the cooperative-run mill. 


\begin{tabular}{ll}
\hline Number of Ejidos and partner communities & 40 \\
Number of landowners & 4620 \\
Total managed forests area & 445676 ha \\
Wood production area & 163452 ha \\
Annual lumber production & $261000 \mathrm{~m}^{3}$ \\
Number of direct permanent jobs & 550 \\
Indirect jobs (estimated) & 2000 \\
Female workforce & $40 \%$ \\
\hline
\end{tabular}

The elemental composition of the biomass and higher heating value used as inputs to Equations 1-12 for the evaluations of technical, economic and environmental performance indicators are shown in Table 4, which are average values for pinewood residues (Martinez-Hernandez et al 2021). The biomass is combusted in a boiler to extract the heat of combustion into a high pressure superheated steam generation at 50 atmospheres. The high pressure superheated steam is then expanded in a back pressure steam turbine to generate electricity. After expansion, low pressure steam at one atmosphere leaves the turbine to meet the steam demand by the sawmill process. A reference biomass price of $25 \$ /$ ton and grid electricity price of $0.0858 \$ / \mathrm{kWh}$ is considered. It also considers that the investment is depreciated, over a plant lifetime of 15 years at an internal rate of return of $10 \%$. The installation factor applied is 1.5 . The annual operating time is $6395 \mathrm{~h} /$ year. The boiler dimensionless energy efficiency is 0.85 . The isentropic and mechanical efficiencies of back pressure steam turbine are 0.85 and 0.9 . The low pressure steam (between $100-115^{\circ} \mathrm{C}$ ) demand by the site is $7831 \mathrm{~kg} / \mathrm{h}$ for the plywood pre-drying and other plant processes. The electricity demand by the site is $3.1975 \mathrm{GWh} / \mathrm{y}$.

Table 4. Average wet analysis values for the typical pine residues.

\begin{tabular}{ll} 
Ultimate analysis $\quad$ Value $\quad$ Unit \\
\hline
\end{tabular}




\begin{tabular}{lcc}
\hline Moisture & 15.0 & $\%$ \\
Ash & 1.4 & $\%$ \\
$\mathrm{C}$ & 44.2 & $\%$ \\
$\mathrm{H}$ & 5.1 & $\%$ \\
$\mathrm{O}$ & 34.0 & $\%$ \\
$\mathrm{~N}$ & 0.3 & $\%$ \\
HHV (dry basis) & 20.28 & $\mathrm{MJ} / \mathrm{kg}$ \\
\hline
\end{tabular}

The two scenarios, as discussed earlier, represent the present bioenergy generation capacity processing readily usable biomass (residues and wastes), and full capacity operation of the CHP using available biomass (generation expansion scenario). In the present scenario, not all local households are supported by the electricity and heat generated by the mill. In the generation expansion scenario, on-site as well as community demands are met.

\section{Bioenergy process, economic, LCA and SLCA modelling results}

Table 5 shows the techno-economic performance comparisons between the two scenarios. Using Equations 1, biomass required is estimated for the two scenarios, 3.5 and $6.5 \mathrm{GWh} /$ year electricity demands, as shown in Table $5.30 \%$ and $56 \%$ of the steam demands $(7831 \mathrm{~kg} / \mathrm{h})$ are met by the CHP configuration in Figure 2 in the present and generation expansion scenario, respectively (using Equation 2). The balance of the steam can be met by an additional boiler capacity (at energy efficiency of 0.85 ). Considering biomass for the CHP configuration (Equation 1) and biomass for the boiler to meet the entire heat demand of the site, the total biomass throughput is $\sim 10$ and $12.5 \mathrm{kt} / \mathrm{year}$, respectively (Table 5). From Table 5, it can be observed that the bioenergy system can export electricity to the communities and that the cost of production can be lower than the cost of consuming electricity via the grid at the domestic tariff in the generation expansion scenario. Thus, providing cheaper electricity to enhance 
livelihoods in local communities can be affordable for the sawmill. This shows the added economic margins due to the economy of scale, albeit requiring a greater initial investment to create enhanced capacity.

Table 5. Techno-economic performance results.

\begin{tabular}{lcc} 
Scenario & Present & Generation expansion \\
\hline Capacity (kW) & 500 & 1000 \\
Electricity generation GWh/year & 3.485 & 6.473 \\
& & \\
Biomass required to cover 100\% heat demand & 9.978 & 12.47 \\
and $\geq 100 \%$ electricity demand (kt wet/year) & & 3.1975 \\
Sawmill process electricity demand (GWh/year) & 3.1975 & 3.275 \\
Electricity surplus to export (GWh/year) & 0.2875 & 1.6 \\
Capital cost (million \$) & 1 & 0.2 \\
Operating cost w/o biomass cost (million \$/year) & 0.1 & 0.3 \\
Biomass cost (million \$/year) & 0.15 & 0.023 \\
Cost of production (\$/kWh) & 0.029 & \\
\hline
\end{tabular}

Sawmill process electricity demands and surplus electricity exports in the two scenarios are established from primary data collection on the sawmill. The capital cost is estimated using Equation 5, from the reference data given: boiler: for $0.62 \mathrm{~kg} / \mathrm{s}$ of biomass, $D C_{i}$ is $\$ 0.4323$ million (Wan et al. 2016a-b), steam turbine and steam system: for $10.3 \mathrm{MW}$ electricity output, $D C_{i}$ is $\$ 5.1$ million (Sadhukhan et al. 2014). In this study, for the boiler capital cost estimations, the biomass flowrates are 0.18 and $0.33 \mathrm{~kg} / \mathrm{s}$ in the two scenarios. For the steam turbine's and steam system's capital cost estimations, the electricity outputs are 0.5 and $1 \mathrm{MW}$ in the two scenarios. Applying the scale factor $_{i}=0.7$, thus, the delivered cost of the boiler 
and the steam turbine and steam system, in million $\$$ is estimated to be 0.18 and $0.28 ; 0.52$ and 0.8 , in the two scenarios, respectively. Applying an installation factor of 1.5 on the total delivered cost of the boiler and the steam turbine and steam system, the capital cost obtained is 1 and 1.6 million $\$$, in the two scenarios, respectively (Table 5).

Amongst the annual operating, capital and biomass costs, the biomass cost is the cost hotspot. However, biomass cost is a source of income generation for local communities and ensuring this price of forestry biomass commodity is essential for socio-economic improvements of the forestry-based poor marginal communities.

The electricity and CHP generation efficiencies are estimated to be $11 \%$ and $62 \%$ using Equations 3 and 4 . This relatively low level of electricity generation efficiency is due to the low pressure superheated steam extraction from the outlet of the back pressure steam turbine. For a scenario with condensate recovery from the back pressure steam turbine, the electricity generation efficiency is $28 \%$ (Wan et al. 2016a-b).

Figure 4 shows the life cycle environmental impact savings by forestry (wood residue) CHP displacing the present fuel oil CHP, in the case study. In comparison to fuel oil CHP, global warming and resource savings are the primary drivers of wood residue CHP. Savings in water, acidification and eutrophication are also considerable. Photochemical ozone formation (urban smog) and ecotoxicity potential savings are lower compared with the other categories. These various levels (high, medium and low) of savings are colour coded accordingly in Figure 4a. Furthermore, the dominance analysis on the wood residue CHP shows that the biomass resource is the primary hot spot in most of the life cycle impact categories. The balance of the impacts come from biomass logistics. Figure $4 \mathrm{~b}$ shows the values of life cycle environmental impact savings on an annual basis. The global warming potential savings in the present and generation expansion scenarios are 3 and $6 \mathrm{kt} \mathrm{CO}_{2}$ eq/y, respectively. The corresponding fossil resource savings are 40 and $74 \mathrm{TJ} / \mathrm{y}$. The various life cycle impact characterisations per $\mathrm{kWh}$ 
electricity generation from the wood residue CHP and the fuel oil CHP (both in Mexico) forming the basis of these results are shown in Table 6. From Table 3, it is also noted that 163452 ha have $12.47 \mathrm{kt} /$ year forestry residues available for the CHP. This gives biomass to land ratio of $7.6 \mathrm{~kg} / \mathrm{m}^{2}$.

In Mexico, the greenhouse gas emissions factor per unit of electricity produced is estimated at $56 \mathrm{~g} \mathrm{CO}_{2} \mathrm{eq} / \mathrm{kWh}$ for the wood residue CHP system while the value for fuel oil CHP system is $959 \mathrm{~g} \mathrm{CO}_{2} \mathrm{eq} / \mathrm{kWh}$. Here, the following important results observed from the LCA using the Ecoinvent 3.0 data sources for the Electricity, high voltage $\{\mathrm{MX}\} \mid$ heat and power cogeneration, wood chips (allocation, cut-off by classification - system).

1. The greenhouse gas sequestration potential by forestry biomass is $1.8 \mathrm{~kg} \mathrm{CO}$ eq/ $/ \mathrm{kg}$.

2. The above greenhouse gas sequestration potential by forestry biomass translates to 1.47 $\mathrm{kg} \mathrm{CO} 2$ eq/kWh electricity generation.

3. The greenhouse gases are emitted by the flue gas from the CHP $(98.6 \%)$, biomass chipping $(0.5 \%)$, diesel consumption in machinery $(0.34 \%)$, biomass harvesting $(0.3 \%)$, biomass forwarding $(0.13 \%)$ and infrastructure $(0.07 \%)$. The greenhouse gas emitted from these life cycle stages is $1.526 \mathrm{~kg} \mathrm{CO}$ eq/ $/ \mathrm{kWh}$ electricity generation. Subtracting the greenhouse gas sequestration by forestry biomass $(1.47 \mathrm{~kg} \mathrm{CO} 2 \mathrm{eq} / \mathrm{kWh}$ electricity generation) from the total greenhouse gas emitted from the various life cycle stages (1.526 $\mathrm{kg} \mathrm{CO} 2 \mathrm{eq} / / \mathrm{kWh}$ electricity generation), the net greenhouse gas emission from the cradle-to-grave $\mathrm{CHP}$ is $56 \mathrm{~g} \mathrm{CO}_{2} \mathrm{eq} / \mathrm{kWh}$. The hotspot is the flue gas emission from the CHP (98.6\%).

Table 6. Comparisons of life cycle impact characterisations between the wood residue CHP and the fuel oil CHP per kWh electricity generation in Mexico.

\begin{tabular}{|c|c|c|c|}
\hline $\begin{array}{l}\text { Impact category per kWh } \\
\text { electricity generation }\end{array}$ & Unit & $\begin{array}{l}\text { Wood residue } \\
\text { CHP }\end{array}$ & Fuel oil CHP \\
\hline Global warming & $\mathrm{kg} \mathrm{CO}_{2} \mathrm{eq}$ & 0.056 & 0.959 \\
\hline Abiotic depletion (fossil fuels) & MJ & 0.62 & 12.01 \\
\hline
\end{tabular}




\begin{tabular}{|l|l|r|r|}
\hline Photochemical ozone formation & $\mathrm{kg} \mathrm{NMVOC} \mathrm{eq}$ & 0.002822 & 0.003996 \\
\hline Acidification & $\mathrm{kg} \mathrm{SO}_{2} \mathrm{eq}$ & 0.002014 & 0.007644 \\
\hline Water consumption & $\mathrm{m}^{3}$ & 0.000157 & 0.001175 \\
\hline Eutrophication & $\mathrm{kg} \mathrm{N} \mathrm{eq}$ & 0.000235 & 0.000505 \\
\hline Ecotoxicity & CTUe & 1.13 & 1.39 \\
\hline
\end{tabular}
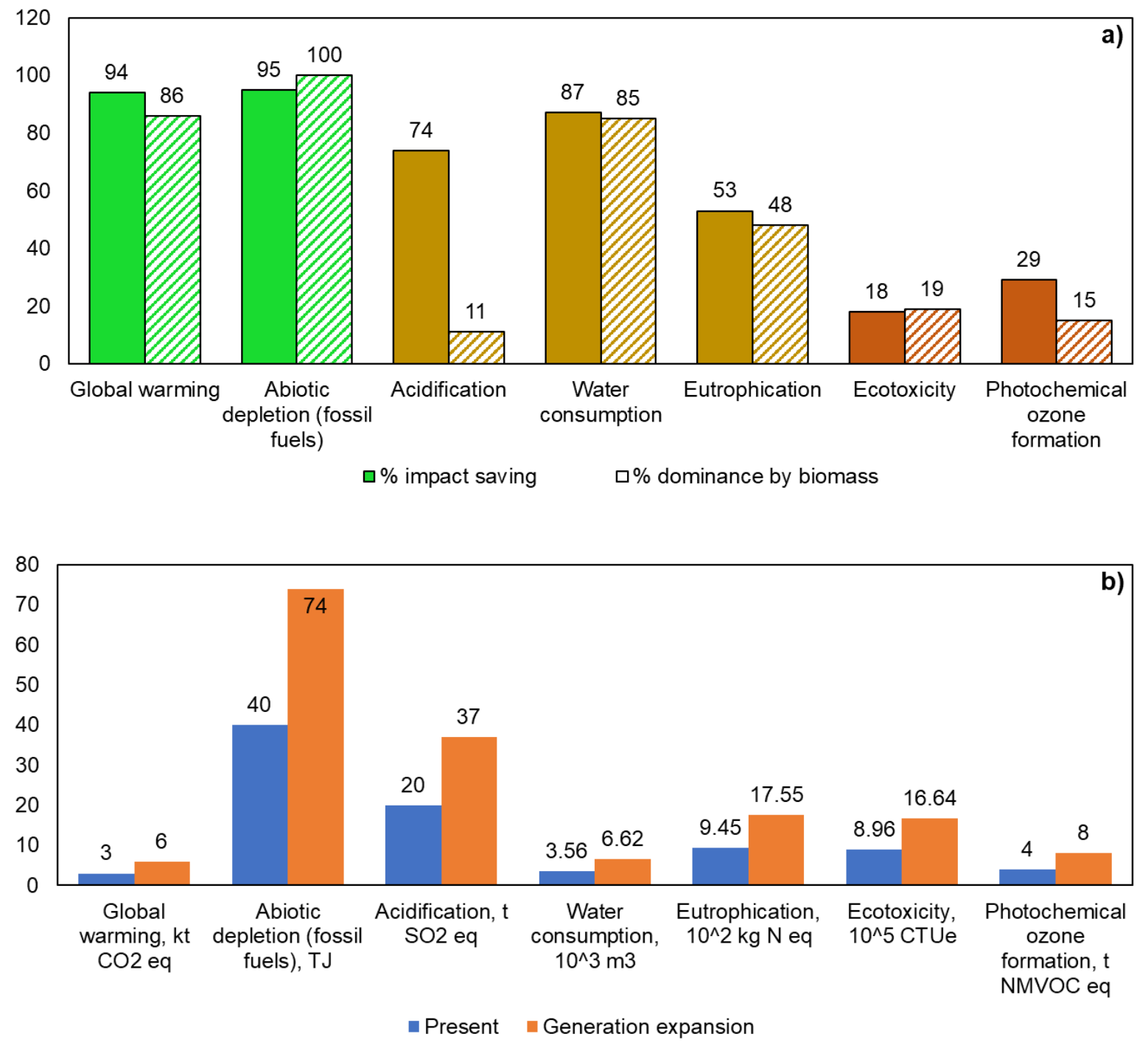

Figure 4. LCA results of a wood-residues CHP referenced to a fuel oil-based CHP system in a Mexican sawmill case study, showing a) percentages of impact savings and percentage of impact dominance by biomass, and b) annual impact savings in the two scenarios.

The SLCA results include a comparison of relative scores, in individual social impact themes as well as overall, between countries participating in SIEPAC, Colombia, Costa Rica, Guatemala, Mexico, Nicaragua and Panama. The basis of the SLCA results comes from the 
SHDB, a proprietary resource (Norris et al. 2014). Because of the paid resource, only relative social impact theme evaluations between countries for the energy sector are shown here. Lower the score better the social impact theme performance is. Thus, which way flow between two countries would improve the social performance can be assessed using the SHDB. The SHDB does not offer any social scores for the two other countries, El Salvador and Honduras, participating in this programme. Figure 5 shows social impact theme scores, scaled between Guatemala (100) and Mexico (1), in overall and five themes (Table 2). The lower the score, the better are the social conditions. Electricity from Mexico can be imported into five countries potentially sharing electricity interconnection systems including Guatemala, Nicaragua, Panama, Colombia and Costa Rica, in decreasing order of overall social impact savings as well as impact savings in the labour rights and decent work themes. In health and safety, impact savings decrease in the following order of countries, Panama, Nicaragua, Guatemala, Colombia and Costa Rica. In human rights, this sequence is Guatemala, Nicaragua, Colombia and Panama. Costa Rica is better performing than Mexico in human rights and governance in the electricity sector. In governance, the decreasing order of impact savings relative to Mexico's can be seen for Nicaragua, Guatemala, Panama and Colombia. In community infrastructure, the highest to the lowest savings relative to Mexico, are obtained for Nicaragua, Panama, Guatemala, Colombia and Costa Rica. All these observations in Figure 5 suggest that exporting average grid electricity from Mexico into these other five SIEPAC countries is desirable for improving social conditions both in the individual countries and across all the countries collectively. The analysis indicates that increasing self-generation of electricity and heat from biomass in Mexico has the potential to not only serve local communities in Mexico (see next section) but by enhancing social conditions in neighbouring countries to Mexico through the transfer of exportable 'surplus' grid electricity from Mexico to these other SEIPAC countries. 


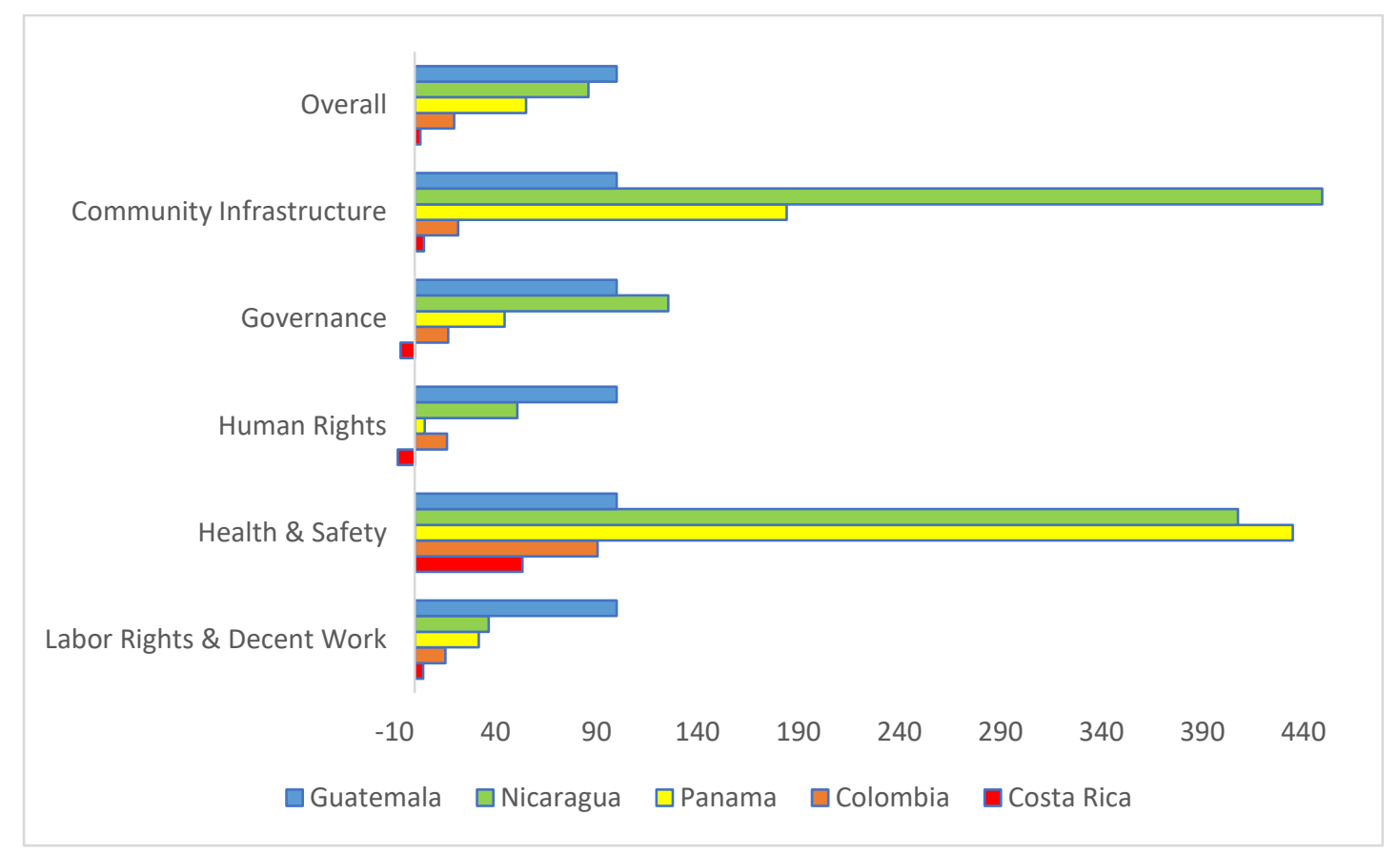

Figure 5. In-country savings in the SLCA themes by electricity import from Mexico.

\section{Discussion including community benefits of bioenergy}

The local community level indicators relevant to the UN SDGs include total forest land managed, job creation and gender equality (Table 3) (SDG 15, SDG8 and SDG5). Furthermore, the SDG6-7 are analysed based on literature data. The analysis of the potential use of excess electricity in the generation expansion scenario to supply energy and water services to the communities local to the case study mill has been carried out to show the improvements in SDG6: clean water and sanitation for all and SDG7: affordable and clean energy. The percentage of households without access to electricity in the various municipalities involved in the forest-based value chain are Canelas: $6.2 \%$, Guanacevi: $6.6 \%$, Otaez: $4.8 \%$, Tamazula: 12.3\%, Tepehuanes: 3.8\%, Topia: 7.5\%, Santiago Papasquiaro: 4.0\%, San Dimas: 6.4\% (CONEVAL 2010). Using the statistics on the total number of households at each municipality, those percentages translate into a total of 2202 households without access to electricity. A sociodemographic study revealed that a rural household in Mexico consumes about 1135 kWh/year of electricity (Franco et al. 2014), which translates into a total demand of 2.5 $\mathrm{GWh} /$ year for the aforementioned municipalities. This means that the expansion generation 
scenario with $3.275 \mathrm{GWh} /$ year of excess electricity could meet the total electricity demand by the rural population living in the aforementioned municipalities and currently lacking access to electricity, although this assumes that electricity access for the population is given priority. Any remaining excess electricity can then be supplied to municipalities for provisioning potable water or sewage water treatment.

In the same municipalities, there is a total of 872 households without access to a water network, and 5114 households without access to a sewage system. Electricity is required for water pumping during extraction and distribution, potabilization and sewage treatment systems. In some cases, capacity for these water services exists, but high operational costs (mainly due to the cost of electricity) prevents municipalities or water service agencies from operating at full capacity (Zurita et al. 2012). The average electricity consumption for municipal water services in Durango was $0.58 \mathrm{kWh} / \mathrm{m}^{3}$ and about $70 \%$ goes to supply potable water and $30 \%$ to sewage treatment (CONUEE 2018). Assuming an average water consumption of $190 \mathrm{~L} /$ person/day and an average of 4 persons per household, the energy required is $0.095 \mathrm{GWh} /$ year for potable water and $0.235 \mathrm{GWh} /$ year for sewage treatment to be provided to the respective number of households lacking these services; a total of $0.33 \mathrm{GWh} /$ year. Furthermore, $(3.275-2.5-$ $0.33)=0.445 \mathrm{GWh} /$ year towards electricity are available for these households without access to clean water and sanitation in these municipalities. Thus, the electricity supply is $(2.5+0.445)=2.945 \mathrm{GWh} /$ year. If water services are given priority over electricity supply to households, the expansion generation scenario can meet this total electricity demand by relevant municipalities for provisioning water services plus the total demand of local households currently lacking access to electricity. The potential co-benefits of wood residue CHP would then enable synergies in the energy-water nexus in the location of the study - this is significant given the link between water supply, sewerage and public health. 
Overall, in this study, the techno-economic and environmental impact modelling and local municipality and neighbouring country social impact modelling show that a substantial improvement is possible in all technical, economic, environmental and social dimensions of sustainability. The results of twenty-nine sustainability indicators analysed for the expansion generation scenario are shown in Figure 6.

This positive environmental and socio-economic impact serves as important evidence in support of investment for deploying forestry and wood residue-based CHP systems in other community managed, forest-based value chains in Mexico. Nowadays, proposed amendments to the Electricity Industry Law are discussed in Mexico. This paper offers relevant technical information for stakeholders to support decisions for bioenergy projects. Together with a revision of government policy and support for bioenergy projects, this can then be translated into enhanced social wellbeing by decreasing social deprivation in energy and water services. Thus, this study presents a market and industry perspective emphasising that bioenergy projects need a transdisciplinary approach, environmentally compatible technology practices, and sustainable supply chains. Investment opportunities should consider fulfilling community demands for foundational services, following the SDG6: clean water and sanitation for all and SDG7: affordable and clean energy, in technology and policy. 


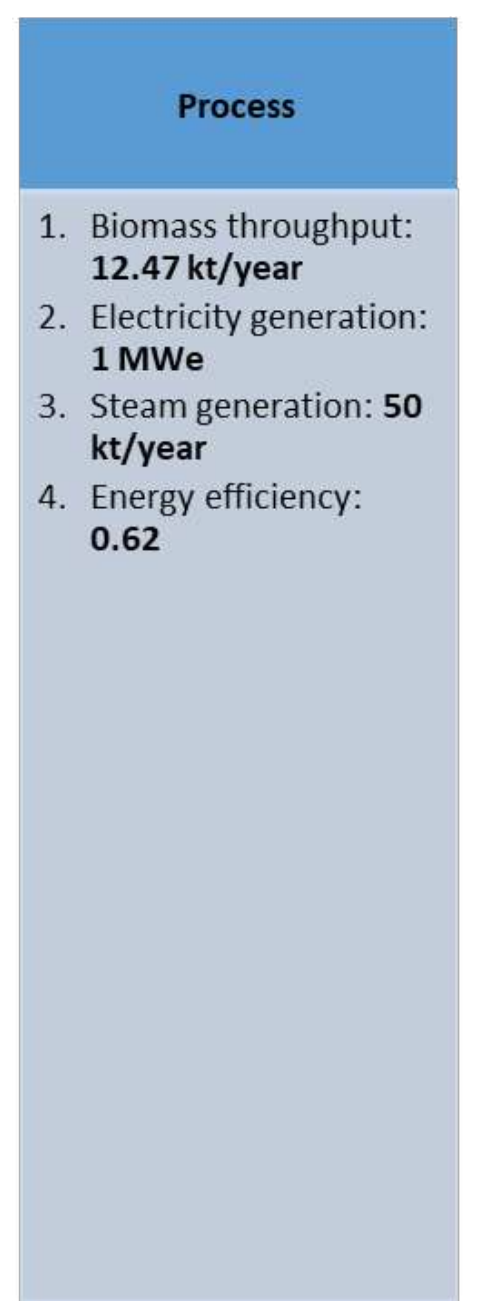

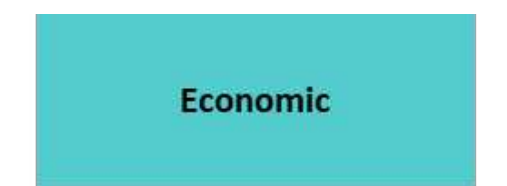

1. Capital cost: $\$ 1.6$ million

2. Internal rate of return: $\mathbf{1 0 \%}$

3. Operating cost: $\$ 0.2$ million/year

4. Feedstock cost: $\$ 0.3$ million/year

5. Cost of production: $\$ 0.023 / \mathrm{kWh}$

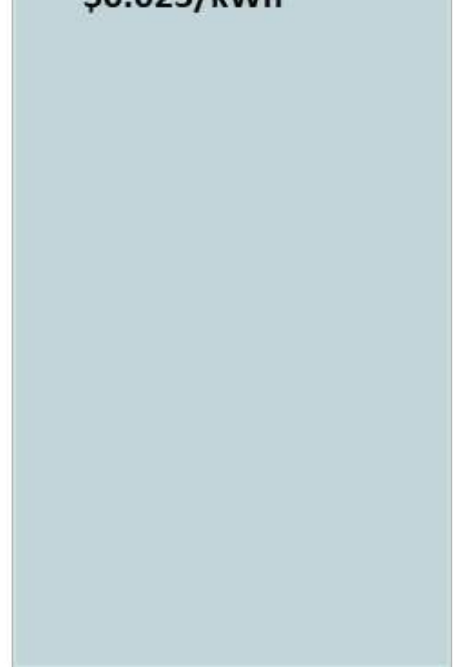

\section{Environmental-LCA (avoidance or saving/year)}

1. Global warming potential (100 yrs): 6 kt $\mathrm{CO}_{2}$ eq.

2. Abiotic depletion potential (fossil fuels): $74 \mathrm{TJ}$

3. Photochemical ozone formation potential: $\mathbf{8}$ t NMVOC eq.

4. Acidification potential: $37 \mathrm{t} \mathrm{SO}{ }_{2}$ eq.

5. Water use: $\mathbf{6 6 2 0} \mathrm{m}^{\mathbf{3}}$

6. Eutrophication potential: $1.755 \mathrm{t} \mathrm{N}$ eq.

7. Ecotoxicity potential: $1.664 \times 10^{6}$ CTUe

8. Sustainable forestry residue availability per land: $7.6 \mathrm{~kg} / \mathrm{m}^{2}$

\section{Social-LCSA (in-country improvements from import from Mexico)}

1. Labour rights and decent work:

Guatemala >

Nicaragua $>$ Panama $>$ Colombia > Costa Rica

2. Health and safety: Panama $>$ Nicaragua

$>$ Guatemala > Colombia > Costa Rica

3. Human rights:

Guatemala >

Nicaragua $>$ Colombia $>$ Panama

4. Governance: Nicaragua >

Guatemala > Panama $>$ Colombia

5. Community infrastructure:

Nicaragua $>$ Panama

$>$ Guatemala > Colombia > Costa Rica
Social-Community SDG

1. Total forest area (SDG15): $\mathbf{4 4 5 6 7 6 \text { ha }}$

2. Direct permanent jobs (SDG8): 550

3. Indirect jobs (SDG8): 2000

4. Gender equality (SDG5): $\mathbf{4 0} \%$ women

5. Energy access (SDG7): $2.945 \mathrm{GWh} /$ year for electrical energy

6. Water access (SDG6): $0.095 \mathrm{GWh} /$ year for potable water access

7. Sanitation access (SDG6): $\mathbf{0 . 2 3 5}$ GWh/year for access to sanitation

Figure 6. Summary of results of twenty-nine sustainability indicators analysed for the expansion generation scenario (1 MWe). 


\section{Conclusions}

This research has critically analysed a wide range of sustainability indicators for bioenergy CHP using whole system life cycle sustainability assessment methodologies. Physicochemical and thermodynamic characteristics are captured in the technical modelling of the system and form the basis for economic and environmental impact analysis. Social impact assessment following the social life cycle assessment guidelines and local community level data are analysed to establish the potential of self-generation in Mexico in serving local communities and for implications for grid interconnection within the SIEPAC framework.

Two scenarios, present and generation expansion corresponding to 0.5 and $1 \mathrm{MW}$ electricity outputs are evaluated. The generation expansion capacity can meet the power and heat demand of the mill as well as the energy demands of the population living in deprivation of access to electricity or the energy demand for supplying water services by the municipalities in the forest-based value chain in Durango state. The cost of electricity generation in the generation expansion scenario $\left(1 \mathrm{MW}_{\mathrm{e}}\right)$ is $\$ 0.023$ per $\mathrm{kWh}$, this cost is lower than the current average grid electricity price. Environmental impact savings of between 20 and 95\% across seven impact categories are found when switching to using bioenergy CHP compared with the conventional fuel oil-based energy system. The social impact assessment showed that exporting electricity from Mexico into Guatemala, Nicaragua, Panama, Colombia and Costa Rica has the potential to enhance social conditions in these SIEPAC countries. The $3.275 \mathrm{GWh} / \mathrm{year}$ of excess electricity generation in the bioenergy generation expansion scenario also has the potential to provide important social benefits locally in Mexico. Apart from potential job generation, this additional electricity supply would be sufficient to meet the whole demand by local households currently lacking electrical supply and demand of municipal energy-water-sanitation services. These findings provide valuable evidence for policymakers, businesses and civil society when considering opportunities to achieve sustainable supplies of energy and water for both local 
and wider as well as SDG6: clean water and sanitation for all and SDG7: affordable and clean energy benefits. The application of the modern web-based open software resource TESARRECTM Trademark: UK00003321198 https://tesarrec.web.app/sustainability/chp has been demonstrated on biomass strategies to meet the net zero greenhouse gas emissions target. Acknowledgement: This work has been supported by The British Council's Newton Fund Impact Scheme Grant Number: 540821111. The authors gratefully acknowledge Sohum Sen developed the TESARREC ${ }^{\mathrm{TM}}$ platform on the web. His CHP module on the TESARREC ${ }^{\mathrm{TM}}$ platform: https://tesarrec.web.app/sustainability/chp has been applied to evaluate the case study. The authors gratefully acknowledge GRUPO SEZARIC ZEPEMIN AR DE IC, Durango, Mexico Sezaric for data on the sawmill and bioenergy system operation for the case study.

\section{References}

Clift R (2014) Social life cycle assessment: What are we trying to do. In Proceedings of PreProceedings of the 4th International Seminar in Social LCA. Social LCA in Progress 19-21 CONEVAL (2010) Methodology for Multidimensional Poverty Measurement in Mexico 2010 de Faria DR, de Medeiros JL, Araújo OQ (2021) Sustainability assessment for the chemical industry: Onwards to integrated system analysis. J Clean Prod 278:123966

CONUEE (2018) Informe nacional de monitoreo de la eficiencia energética de México

Ecchevarria C, Jerusun-Clements N, Mercado J et al (2017) Integración eléctrica centroamericana: Génesis, beneficios y prospectiva del Proyecto SIEPAC. Sistema de Interconexión Eléctrica de los Países de América Central Publications

Emmanuel-Yusuf D, Morse S, Leach M (2017) Resilience and livelihoods in supply chains (RELISC): An analytical framework for the development and resilience of the UK wood fuel sector. Sustain 9(4):660 
Fitzpatrick JJ (2016) Environmental sustainability assessment of using forest wood for heat energy in Ireland. Ren Sustain Energy Rev 57:1287-1295

Franco A, Velázquez M (2016) Una aproximación sociodemográfica al consumo de energía en los hogares mexicanos, 2014. In: Márquez Villeda M Ed. La situación demográfica México

González-Cruz LA, Morales-Mendoza LF, Aguilar-Lasserre AA et al (2021) Optimal ecodesign selection for biodiesel production in biorefineries through multicriteria decision making. Clean Technol Environ Policy 1-20

Halog A, Manik Y (2011) Advancing integrated systems modelling framework for life cycle sustainability assessment. Sustain 3(2):469-499

Honorato-Salazar JA, Sadhukhan J (2020) Annual biomass variation of agriculture crops and forestry residues, and seasonality of crop residues for energy production in Mexico. Food Bioprod Process 119:1-19

Klein SA (2017) TRNSYS-A transient system simulation program. Solar Energy Laboratory. University of Wisconsin-Madison

Luján-Álvarez C, Miguel Olivas-García J, Guadalupe González-Hernández H et al (2015) Community forestry in Mexico: strategic model for the empowerment and competitiveness in globalization. Econ Soc y Territ 15:665-96

Martinez-Hernandez E, Amezcua-Allieri MA, Aburto J (2021) Assessing the cost of biomass and bioenergy production in agroindustrial processes. Energies 14:4181

Martinez-Hernandez E, Ibrahim MH, Leach M et al (2013) Environmental sustainability analysis of UK whole-wheat bioethanol and CHP systems. Biomass Bioenergy 50:52-64 
Martinez-Hernandez E, Martinez-Herrera J, Campbell GM et al (2014) Process integration, energy and GHG emission analyses of Jatropha-based biorefinery systems. Biomass Conv Bioref 4(2):105-124

Martinez-Hernandez E, Samsatli S (2017) Biorefineries and the food, energy, water nexus towards a whole systems approach to design and planning. Curr Opin Chem Eng 18:16-22

Ng KS, Lopez Y, Campbell GM et al (2010) Heat integration and analysis of decarbonised IGCC sites. Chem Eng Res Des 88(2):170-188

Ng KS, Zhang N, Sadhukhan J (2013) Techno-economic analysis of polygeneration systems with carbon capture and storage and CO2 reuse. Chem Eng J 219:96-108

Niekamp S, Bharadwaj UR, Sadhukhan J et al (2015) A multi-criteria decision support framework for sustainable asset management and challenges in its application. J Ind Prod Eng 32(1):23-36

Norris C, Norris G, Aulisio D (2014) Efficient assessment of social hotspots in the supply chains of 100 product categories using the social hotspots database. Sustain 6:6973-84

Ong SH, Tan RR, Andiappan V (2021) Optimisation of biochar-based supply chains for negative emissions and resource savings in carbon management networks. Clean Technol Environ Policy 23(2):621-638

Petersen AM, Okoro OV, Chireshe F et al (2021) Systematic cost evaluations of biological and thermochemical processes for ethanol production from biomass residues and industrial offgases. Energy Conv Manage 243:114398

Puig-Gamero M, Pio DT, Tarelho LAC et al (2021) Simulation of biomass gasification in bubbling fluidized bed reactor using aspen plus®. Energy Conv Manage 235:113981 
Rezaei M, Sameti M, Nasiri F (2021) Biomass-fuelled combined heat and power: integration in district heating and thermal-energy storage. Clean Energy 5(1):44-56

Roos A, Ahlgren S (2018) Consequential life cycle assessment of bioenergy systems-a literature review. J Clean Prod 189:358-373

Sadhukhan J, Gadkari S, Martinez-Hernandez E et al (2019b) Novel macroalgae (seaweed) biorefinery systems for integrated chemical, protein, salt, nutrient and mineral extractions and environmental protection by green synthesis and life cycle sustainability assessments. Green Chem 21(10):2635-2655

Sadhukhan J, Martinez-Hernandez E (2017) Material flow and sustainability analyses of biorefining of municipal solid waste. Bioresour Technol 243:135-146

Sadhukhan J, Martinez-Hernandez E, Amezcua-Allieri MA et al (2019a) Economic and environmental impact evaluation of various biomass feedstock for bioethanol production and correlations to lignocellulosic composition. Bioresour Technol Rep 7:100230

Sadhukhan J, Ng KS, Martinez-Hernandez E (2014) Biorefineries and Chemical Processes: Design, Integration and Sustainability Analysis. Wiley

Sadhukhan J, Sen S, Gadkari S (2021) The Mathematics of life cycle sustainability assessment. J Clean Prod 309:127457

Sadhukhan J, Zhang N, Zhu XX (2004) Analytical optimisation of industrial systems and applications to refineries, petrochemicals. Chem Eng Sci 59(20):4169-4192

Sadhukhan J, Zhao Y, Shah N et al (2010) Performance analysis of integrated biomass gasification fuel cell (BGFC) and biomass gasification combined cycle (BGCC) systems. Chem Eng Sci 65(6):1942-1954 
Sahu P, Prabu V (2021) Techno-economic analysis of co-combustion of Indian coals with municipal solid waste in subcritical and supercritical based steam turbine power generating carbon-negative systems. Energy, 121053

Sen S (2020) TESARRECTM. University of Surrey https://tesarrec.web.app/sustainability/chp

Sikdar SK (2003) Sustainable development and sustainability metrics. AIChE J 49(8):19281932

United Nations Sustainable Development Goals (2015)

Visentin C, da Silva Trentin AW, Braun AB et al (2020) Life cycle sustainability assessment: A systematic literature review through the application perspective, indicators, and methodologies. J Clean Prod 270:122509

Wan YK, Sadhukhan J, Ng DK (2016b) Techno-economic evaluations for feasibility of sagobased biorefinery, Part 2: Integrated bioethanol production and energy systems. Chem Eng Res Des 107:102-116

Wan YK, Sadhukhan J, Ng KS et al (2016a) Techno-economic evaluations for feasibility of sago-based biorefinery, Part 1: Alternative energy systems. Chem Eng Res Des 107:263279

Wang J, Yang Y, Bentley Y et al (2018) Sustainability assessment of bioenergy from a global perspective: A review. Sustain 10(8):2739

Żołądek M, Figaj R, Sornek K (2021) Energy analysis of a micro-scale biomass cogeneration system. Energy Conv Manage 236:114079

Zurita F, Roy ED, White JR (2012) Municipal wastewater treatment in Mexico: Current status and opportunities for employing ecological treatment systems. Environ Technol 33:1151-8 


\section{Supplementary Files}

This is a list of supplementary files associated with this preprint. Click to download.

- graphicalabstract1.docx 